\title{
Galanin Receptor-Mediated Inhibition of Glutamate Release in the Arcuate Nucleus of the Hypothalamus
}

\author{
Gregory A. Kinney, Paul J. Emmerson, and Richard J. Miller \\ Department of Pharmacological and Physiological Sciences, The University of Chicago, Chicago Illinois, 60637
}

It is thought that galanin, a 29 amino acid neuropeptide, is involved in various neuronal functions, including the regulation of food intake and hormone release. Consistent with this idea, galanin receptors have been demonstrated throughout the brain, with high levels being observed in the hypothalamus. However, little is known about the mechanisms by which galanin elicits its actions in the brain. Therefore, we studied the effects of galanin and its analogs on synaptic transmission using an in vitro slice preparation of rat hypothalamus. In arcuate nucleus neurons, application of galanin resulted in an inhibition of evoked glutamatergic EPSCs and a decrease in paired-pulse depression, indicating a presynaptic action. The fragments galanin 1-16 and 1-15 produced a robust depres-

Galanin, a 29 amino acid neuroregulatory peptide, has been implicated in numerous neuronal functions including feeding behavior (Crawley et al., 1990; Kyrkouli et al., 1990) and regulation of hormone release (Bauer et al., 1986; Bjorkstrand et al., 1993; Kondo et al., 1993; Sahu et al., 1994; Rossmanith et al., 1996). These two effects of galanin are thought to result from its actions within the hypothalamus. Galanin receptor binding has been demonstrated to be high within the hypothalamus, particularly within the arcuate and paraventricular nuclei (Skofitsch and Jacobowitz, 1985; Melander et al., 1986; Vrontakis et al., 1991; Merchenthaler et al., 1993). Thus, galanin very likely plays a significant role in hypothalamic function, although the mechanisms underlying its actions are unclear.

Two galanin receptors, GALR1 and GALR2, have been cloned to date (Habert-Ortoli et al., 1994; Howard et al., 1997). Binding and other studies using galanin analogs have indicated that additional subtypes of galanin receptors are likely to exist. Chimeric peptides C7, M40, M32, and M15 have been show to act as galanin antagonists in certain systems, including feeding behavior (Bartfai et al., 1993; Corwin et al., 1993; Crawley et al., 1993), stimulation (Pramanik and Ögren, 1993) and inhibition (Bartfai et al., 1991, 1993; Lindskog et al., 1992) of acetylcholine release in the striatum and hippocampus, respectively, inhibition of glutamate and aspartate release in the hippocampus (Zini et al., 1993),

\footnotetext{
Received Oct. 14, 1997; revised Feb. 18, 1998; accepted Feb. 25, 1998.

This work was supported by Public Health Service Grants DA02121, DA02575, MH40165, NS33502, DK42086, and DK44840. We thank Drs. Daniel McGehee and Aaron Fox for their technical expertise.

Correspondence should be addressed to Dr. Richard J. Miller, Department of Pharmacological and Physiological Sciences, 947 E. 58th Street, MC 0926, Chicago, IL 60637.

Dr. Kinney's present address: Department of Physiology and Biophysics, Veterans Affairs Medical Center, Seattle, WA 98108-1597.

Copyright (C) 1998 Society for Neuroscience $\quad 0270-6474 / 98 / 183489-12 \$ 05.00 / 0$
}

sion of synaptic transmission, whereas the fragment 3-29 produced a lesser degree of depression. The chimeric peptides C7, M15, M32, and M40, which have been reported to antagonize some actions of galanin, all produced varying degrees of depression of evoked EPSCs. In a minority of cases, C7, M15, and M40 antagonized the actions of galanin. Analysis of mEPSCs in the presence of TTX and $\mathrm{Cd}^{2+}$, or after application of $\alpha$-latrotoxin, indicated a site of action for galanin downstream of $\mathrm{Ca}^{2+}$ entry. Thus, our data suggest that galanin acts via several subtypes of presynaptic receptors to depress synaptic transmission in the rat arcuate nucleus.

Key words: galanin; galanin receptors; transmitter release; presynaptic; depression; EPSC; mEPSC and stimulation of luteinizing hormone release (Sahu et al., 1994). However, in other systems, such as galanin-mediated inhibition of cAMP accumulation in RINm5F cells (Bartfai et al., 1993), inhibition of glucose-induced insulin release (Bartfai et al., 1993), facilitation of the spinal cord reflex (Bartfai et al., 1993), mobilization of intracellular $\mathrm{Ca}^{2+}$ stores (Fridolf and Ahrén, 1993), and hyperpolarization of magnocellular neurosecretory cells (Papas and Bourque, 1997), these same compounds are inactive or act as partial or full agonists. In addition, the galanin fragments 1-15 and 3-29 have been shown to behave as full agonists in some preparations (Wynick et al., 1993; Hedlund et al., 1994; Lorinet et al., 1994), whereas they have no effect in others (Wynick et al., 1993; Lorinet et al., 1994), again suggesting the existence of additional galanin receptor subtypes.

Recent work has identified various cellular effects, typical of G-protein-linked receptors, through which galanin might regulate neuronal function. Galanin is capable of opening $\mathrm{K}^{+}$channels and hyperpolarizing neurons (Ahrén et al., 1989; Dunne et al., 1989; Konopka et al., 1989; Parsons and Merriam, 1992; Papas and Bourque, 1997), inhibiting adenylate cyclase activity (Nishibori et al., 1988; Chen et al., 1992), inhibiting voltage-gated $\mathrm{Ca}^{2+}$ channels (Merriam and Parsons, 1995), inhibiting phosphoinositide turnover (Palazzi et al., 1988), and regulating the release of dopamine (Nordström et al., 1987), noradrenaline (Tsuda et al., 1989), acetylcholine (Fisone et al., 1987; Ögren and Pramanik, 1991; Ögren et al., 1993), and glutamate (Zini et al., 1993). The regulation of transmitter release is an important mechanism by which galanin could potentially modulate neuronal function. However, few studies to date have directly investigated these actions of galanin. We have now investigated the ability of galanin to modulate synaptic transmission within the arcuate nucleus of the hypothalamus. Our results indicate that galanin acts through multiple presynaptic receptors to inhibit the release process. 


\section{MATERIALS AND METHODS}

Preparation of brain slices. The methods for the preparation of thin hypothalamic brain slices were similar to those described previously (Glaum et al., 1994). Experiments were conducted on Wistar rats of either sex, age 10-20 d postnatal. Animals were anesthetized with ether by inhalation, and killed by decapitation using a guillotine. The brain was removed rapidly by dissection and placed in chilled $\left(0-6^{\circ} \mathrm{C}\right)$ extracellular solution of the following composition (in $\mathrm{mM}$ ): $\mathrm{NaCl} 126, \mathrm{KCl} 3, \mathrm{CaCl}_{2}$ 2.5, $\mathrm{MgSO}_{4} 1.3, \mathrm{NaH}_{2} \mathrm{PO}_{4} 1.25, \mathrm{NaHCO}_{3} 26$, and D-glucose 10 (gassed with $95 \% \mathrm{O}_{2} / 5 \% \mathrm{CO}_{2}$, pH 7.4; osmolarity = $310 \mathrm{mOsm}$ ). Thin (200- to $220-\mu \mathrm{m}$-thick) coronal slices of the arcuate nucleus of the hypothalamus were cut using a vibrating tissue chopper (Vibratome). Slices were maintained at $30-32^{\circ} \mathrm{C}$ until needed for recording.

For recording, slices were transferred to a submersion chamber mounted on the stage of an upright microscope (Leitz Laborlux) and viewed with a Zeiss $40 \times$ water immersion objective with Hoffman Contrast Optics. The slices were perfused continuously throughout the experiment with extracellular solution at room temperature $\left(20-25^{\circ} \mathrm{C}\right)$. All recordings were made from visually identified neurons located in the arcuate nucleus. The arcuate nucleus is rich in galanin-positive neuronal cell bodies and may be an important structure in the regulation of reproduction and food intake (Landry et al., 1995).

Patch-clamp recording, synaptic stimulation, and data analysis. Patchclamp recording pipettes were made from thin-walled borosilicate glass capillaries (DC resistance $=5-10 \mathrm{M} \Omega$ when filled with internal solution) using a Flaming-Brown horizontal pipette puller (Sutter Instruments). In all experiments, electrodes were filled with internal solution of the following composition (in $\mathrm{mM}$ ): potassium gluconate $145, \mathrm{MgCl}_{2} 2$, $\mathrm{K}_{2}$ ATP 5, EGTA 1.1, $\mathrm{CaCl}_{2}$ 0.1, and HEPES 5, pH 7.2; osmolarity adjusted to 280-290 mOsm. Patch recording pipettes were mounted in the headstage attached to a stage-mounted three-way hydraulic micromanipulator (Narashige) and positioned over the somas of neurons under visual control. Conventional methods for obtaining whole-cell recordings from thin slices (Hamill et al., 1981; Edwards et al., 1989) were used. After the attainment of cell access, transmembrane voltage and current were recorded using an Axoclamp 2B (Axon Instruments, Foster City, CA) amplifier in the discontinuous voltage-clamp mode (filtered at $5 \mathrm{kHz}$ and acquired at $20 \mathrm{kHz}$ ), stored on a Pentium computer (Quantex) and via chart recorder (Gould), and analyzed using pClamp 6.0.1 (Axon Instruments).

Bipolar tungsten stimulating electrodes were placed lateral to the arcuate nucleus to activate inputs to arcuate nucleus neurons. In all experiments, stimuli of between 50 and $500 \mu \mathrm{sec}$ were used to elicit synaptic responses and were maintained at $10 \mathrm{sec}$ intervals to record the time-dependent effects of drug perfusion. Paired-pulse stimuli were recorded at a $20 \mathrm{sec}$ interval using a $30 \mathrm{msec}$ interpulse interval. In normal saline, the paired-pulse ratio was a random mixture of both paired-pulse facilitation and depression that likely resulted from the polysynaptic inputs recorded in arcuate neurons. Therefore, studies of paired stimuli were recorded in high $\mathrm{Ca}(5 \mathrm{~mm})$ and low $\mathrm{Mg}(0.5 \mathrm{~mm})$ saline solution, which increases the probability of neurotransmitter release in response to the initial stimulus and favors paired-pulse depression (Khazipov et al., 1995; Dobrunz and Stevens, 1997). These recording conditions significantly improved the reproducibility of the paired-pulse ratio recorded from arcuate neurons. For the purposes of data analysis, 2-3 min of evoked EPSCs were averaged (12-18 EPSCs), and the peak of the averaged EPSC was measured. Cells that responded to drug application with a $15 \%$ or greater reduction (a change greater than the $99 \%$ confidence limits of the control window mean) were considered to have responded positively. Data are expressed in mean \pm SEM.

Recording and analysis of mEPSCs. Miniature EPSCs (mEPSCs) were recorded from arcuate nucleus neurons at a holding potential of -60 to $-70 \mathrm{mV}$ in the presence of $1 \mu \mathrm{M}$ TTX, $40 \mu \mathrm{M}$ 7-chlorokynurenic acid, 10 $\mu \mathrm{M}$ bicuculline, and, unless noted otherwise, $100 \mu \mathrm{M}$ cadmium chloride $\left(\mathrm{Cd}^{2+}\right)$. Currents were filtered at $1-2 \mathrm{kHz}$, sampled at $8 \mathrm{kHz}$, and acquired to disk using pClamp software. Cells were monitored periodically for changes in access resistance, and cells that exhibited any significant $(>15 \%)$ changes during the recording period were rejected.

mEPSCs were analyzed using pClamp software or software written by Drs. Andreas Kyrozis, Romain Girod, and Daniel McGehee in Axobasic specifically for the analysis of mEPSCs. This program allows for the automatic screening of events based on amplitude or $10-90 \%$ rise time or both. All events were examined visually and accepted or rejected on the basis of subjective visual criteria as well as the objective criteria of amplitude, rise time, and decay time. Events that had an amplitude of $>4$
pA, rise times of between $300 \mu \mathrm{sec}$ and $3 \mathrm{msec}$, and decay times of between 3 and $30 \mathrm{msec}$ were included in the analysis.

Analyzed data from a 3-5 min recording period (100-1000 events) were examined and further analyzed using Prism (Graphpad) and Statmost (Datamost). Cumulative probability plots were constructed to visually examine the effects of galanin on the amplitude and interval distributions of mEPSCs, whereas amplitude and interval distributions were compared statistically using a Kolmogorov-Smirnov test or a Student's unpaired $t$ test with Welch's correction. Differences in distributions were considered significant if $p<0.05$. Data are expressed in mean \pm SEM.

Application of drugs. Drugs were dissolved in distilled water or DMSO $(\leq 0.1 \%$ final concentration in artificial CSF) and applied by bath perfusion. The following compounds were used: bicuculline methobromide (Sigma, St. Louis, MO), 7-chlorokynurenic acid (Tocris Cookson), D,L2-amino-5-phosphonpentanoic acid (D,L-AP5) (Tocris Cookson), TTX (Sigma), $\alpha$-latrotoxin (Alomone Labs), (rat) galanin (American Peptides), galanin 1-16 (Bachem, Torrance, CA), galanin 1-15, 3-29, and M32 (gifts of Mary Walker, Synaptic Pharmaceuticals), galantide (M15) (American Peptides), M40 (American Peptides), and C7 (American Peptides). All drugs, with the exception of AMPA and $\alpha$-latrotoxin, were applied for between 5 and $10 \mathrm{~min}$ to obtain a steady-state bath concentration. AMPA was applied 2-3 times in succession $(25 \mu \mathrm{M}$ for a period of $40 \mathrm{sec}$ at $10 \mathrm{~min}$ intervals) to achieve a series of rapid inward currents ( -60 to $-150 \mathrm{pA}$ ), which were then averaged. In the case of $\alpha$-latrotoxin, it was found that the time required for action of the toxin in an in vitro slice preparation was unfeasible; thus, slices were incubated for $2 \mathrm{hr}$ in 2 $\mathrm{nM} \alpha$-latrotoxin and then transferred to the recording chamber, where the slice was then perfused with standard extracellular Ringer's solution. The effects of $\alpha$-latrotoxin are likely irreversible within the time course of this experiment (Wanke et al., 1986; Capogna et al., 1996a,b), and thus there should be no significant "washout" of its effects during the recording period. Such extensive exposure to $\alpha$-latrotoxin could result in some depletion of transmitter stores (Tzeng et al., 1978; Hurlbut et al., 1990; McMahon et al., 1990; Storchak et al., 1994), as well as some loss of synaptic morphology (Tzeng et al., 1978). Under these conditions, however, a much greater percentage of cells ( $\sim 80 \%)$ was observed than under control conditions $(\sim 25 \%)$, which displayed an mEPSC frequency adequate for analysis $(>0.5 \mathrm{~Hz})$ (see Results).

\section{RESULTS}

Whole-cell patch recordings were obtained from 110 neurons in 65 preparations of $200-220 \mu \mathrm{M}$ thick slices of rat arcuate nucleus. Unless noted otherwise, all experiments were performed at a cell holding potential of between -60 and $-70 \mathrm{mV}$ in the presence of bicuculline $(10 \mu \mathrm{M}), 7$-chlorokynurenic acid $(40 \mu \mathrm{M})$, and $1.5 \mathrm{~mm}$ external $\mathrm{Mg}^{2+}$ to pharmacologically isolate the AMPA receptormediated EPSCs. The mean cellular input resistance was $1200 \pm$ $74 \mathrm{M} \Omega(n=71)$. The mean $10-90 \%$ rise time was $2.14 \pm 0.09$ msec $(n=50)$, and the mean $10-90 \%$ decay was $12.77 \pm 0.49$ msec $(n=50)$. No significant differences in values were observed between control and drug application, so the values were pooled. The figure for the 10-90\% rise time indicates that many of the synaptic responses recorded were the result of multiple asynchronous inputs.

\section{Galanin receptor-mediated synaptic depression}

To investigate the effects of galanin on synaptic transmission in the hypothalamus, a stimulating electrode was placed ventrolateral to the arcuate nucleus, and synaptic inputs were stimulated at a frequency of $0.1 \mathrm{~Hz}$ while recording from arcuate neurons in the discontinuous voltage-clamp mode. In the presence of 7-chlorokynurenic acid and bicuculline, stimulation of inputs resulted in exclusively AMPA receptor-mediated EPSCs (Glaum et al., 1996). Under such conditions, application of galanin (galanin 1-29, $100 \mathrm{nM}$ ) caused a strong reduction of synaptic transmission in 19 of 26 cases examined $(55.54 \pm 4.03 \% ; n=19)$ (Figs. 1 $A, 2)$. In cases in which a sufficient washout period was recorded, there was some variability in the degree of recovery observed. In some 
A

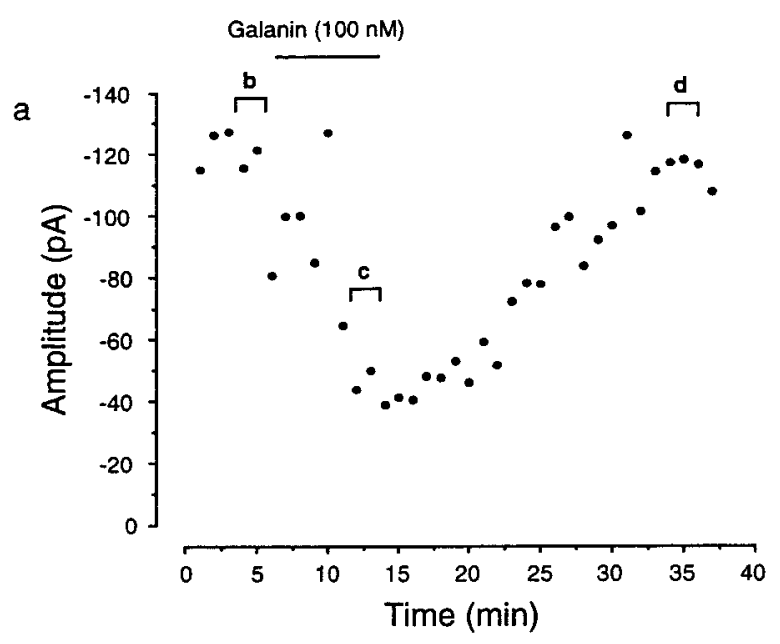

b

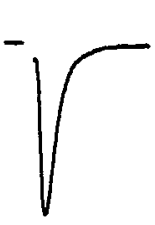

Control c

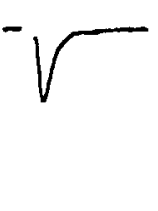

Galanin (100nM) d

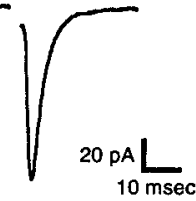

Wash $10 \mathrm{msec}$

B

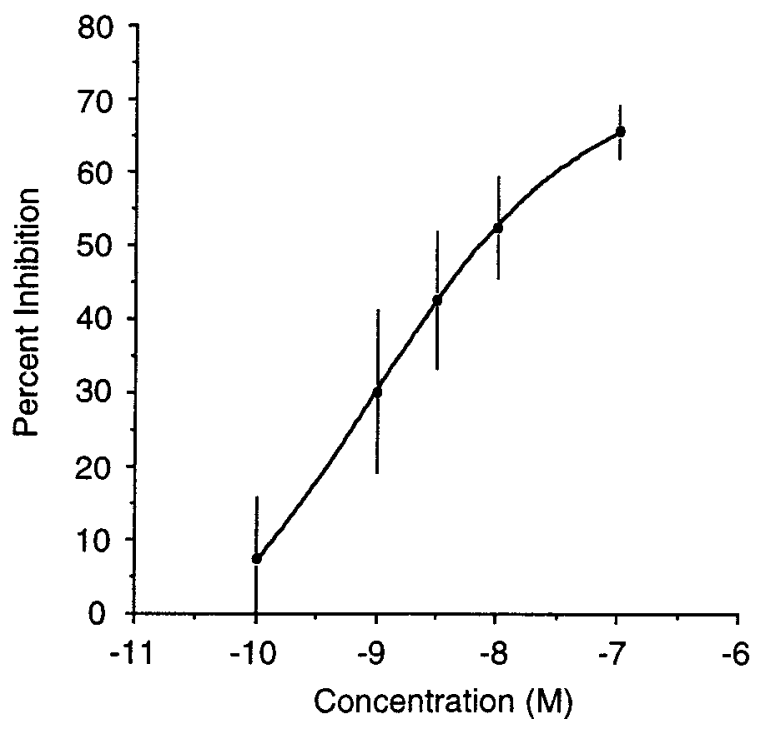

Figure 1. Application of galanin caused a depression of AMPA receptormediated synaptic transmission in the arcuate nucleus. $A$, Application of $100 \mathrm{~nm}$ galanin caused a depression in the evoked EPSC, as recorded from an arcuate nucleus neuron. After washout of the drug, the EPSC recovered to control levels within $20 \mathrm{~min}$. For $A, a$ represents the time course of the effects of galanin on synaptic transmission, whereas $b-d$ are averaged EPSCs taken from the respective cells showing EPSCs before drug application $(b)$, during drug application $(c)$, and after washout of the drug (d). $B$, Dose-response curve for galanin. Application of progressively higher doses of galanin (0.1-100 nM) resulted in a dose-dependent decrease in the amplitude of evoked synaptic currents $(n=5)$, as recorded from arcuate nucleus neurons. Data are mean \pm SEM.

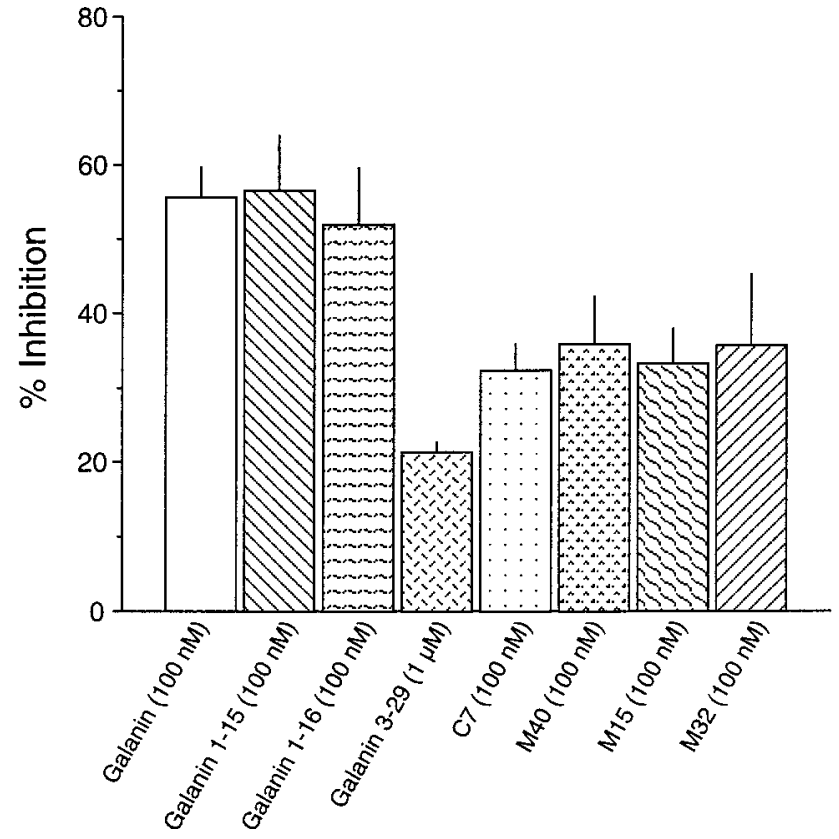

Figure 2. Histogram representing the degree of inhibition of the evoked EPSC by the different galanin analogs. Vertical bars represent the absolute magnitude of inhibition produced by each of the compounds tested in this study, as marked below each bar. The numbers of observations for each compound are as follows (number of positive trials per total number of trials): galanin (19 of 26), galanin 1-16 (7 of 9), galanin 1-15 (4 of 10), galanin 3-29 (4 of 11), C7 (7 of 15), M40 (10 of 15), M15 (9 of 12), M32 (3 of 3 ). Data are mean \pm SEM.

cells the effect of galanin readily reversed during washout (Fig. $1 A)$. However, in six cells there was a slow and incomplete recovery observed after a long (+40 min) washout period (data not shown). Such variability was observed with galanin 1-15 and galanin 1-16 as well (see below). These observations are consistent with previous reports of long-lasting actions of other peptides in the hypothalamus (Van den Pol et al., 1996; Rhim et al., 1997)

The dose-response relationship for the effect of galanin on synaptic transmission was investigated by bath applying the peptide in increasing doses to slices while evoked EPSCs were recorded. The concentration producing a maximal effect was determined to be $\sim 100 \mathrm{nM}$, with an $\mathrm{EC}_{50}$ of $0.85 \mathrm{nM}(n=5)$ (Fig. $\left.1 B\right)$.

To investigate the types of galanin receptors mediating inhibition of the EPSC, various galanin analogs were tested. Galanin (1-15) and (1-16) are N-terminal fragments of galanin, whereas galanin 3-29 is a galanin fragment truncated at the $\mathrm{N}$ terminus. Application of both galanin 1-15 (100 nM) and galanin 1-16 (100 $\mathrm{nM}$ ) resulted in a depression of evoked EPSCs (Figs. 2, 3A,B). Although both fragments caused a similar degree of inhibition $(1-15: 56.56 \pm 7.28 \%, n=4 ; 1-16: 51.84 \pm 7.60 \%, n=7)$, galanin $1-16$ acted on a larger group of cells (seven of nine) than galanin 1-15 (4/10). Strikingly, galanin 1-16 was effective on some cells in which galanin 1-15 had no effect (four of five cells) (Fig. 3B). Galanin 3-29 (100 nм to $1 \mu \mathrm{M}$ ) was much less potent, causing a moderate inhibition in only 4 of 11 cells $(21.28 \pm 1.37 \%)$ (Figs. 2, $3 C)$. In one cell on which galanin was also applied, the degree of inhibition mediated by galanin was much greater. In addition, galanin caused inhibition in each of the cells that did not respond to galanin 3-29 (Fig. 3C).

Various putative galanin antagonists have been reported (Bartfai et al., 1991, 1993; Lindskog et al., 1992; Pramanik and 
A

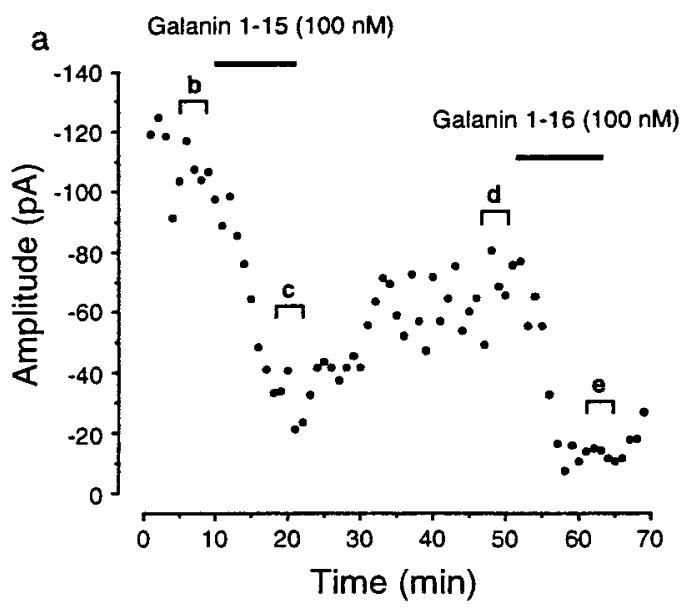

b<smiles>CC=CCC</smiles>

Control

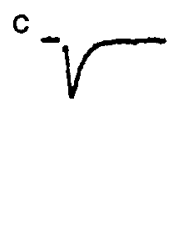

Galanin $1-15$
$(100 \mathrm{nM})$

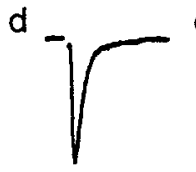

e

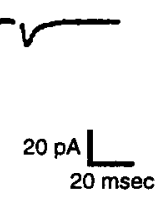

Wash

Galanin 1-16 (100nM)

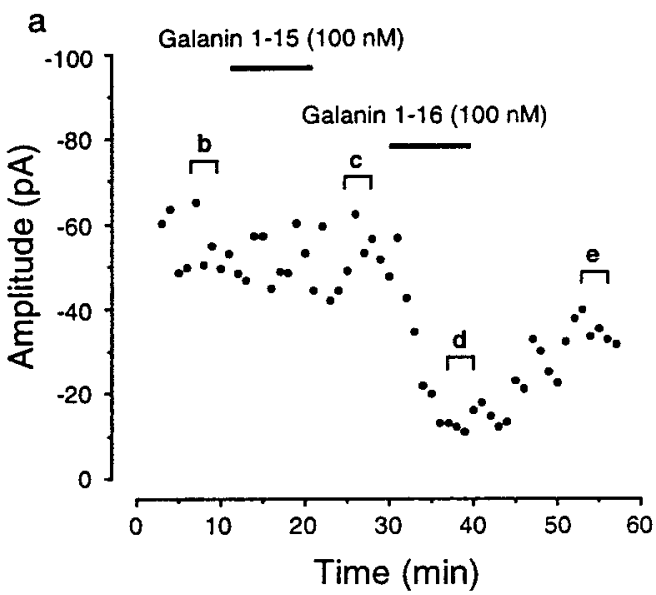

b

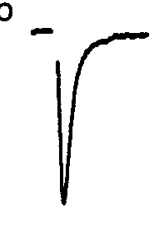

Control
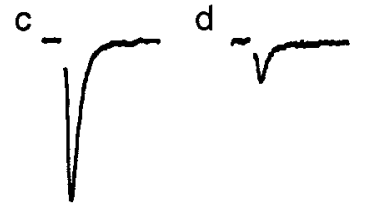

Galanin 1-15 (100nM) (100nM)

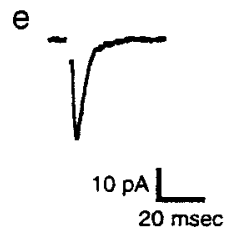

$20 \mathrm{msec}$

Wash

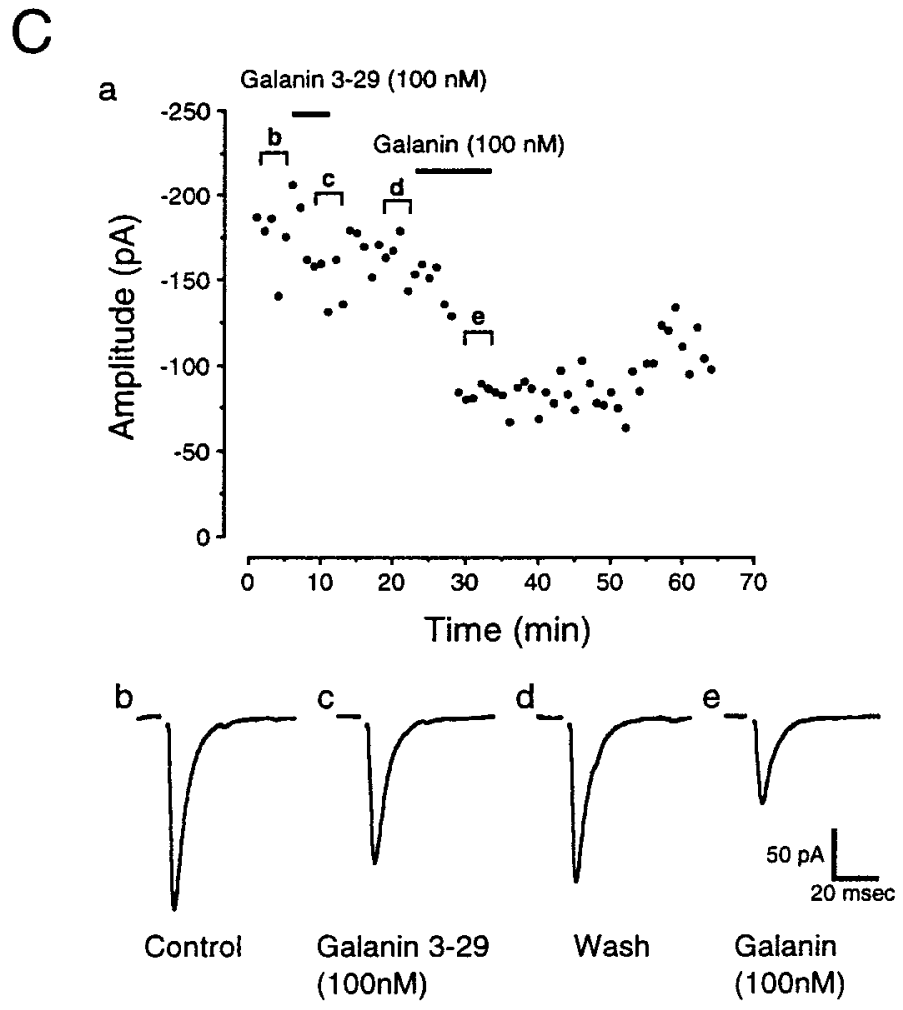

Figure 3. Application of galanin 1-15, 1-16, and 3-29 caused a depression of AMPA receptor-mediated synaptic transmission in the arcuate nucleus. $A$, Application of $100 \mathrm{nM}$ galanin 1-15 caused a depression in the evoked EPSC, as recorded from an arcuate nucleus neuron. After washout of the drug, the EPSC partially recovered. Application of $100 \mathrm{~nm}$ galanin 1-16 after washout resulted in a nearly complete depression of the synaptic response. $B$, Application of $100 \mathrm{~nm}$ galanin 1-15 to another cell failed to elicit a response. However, application of galanin 1-16 after washout resulted in a significant depression of transmission. $C$, In another cell, application of $100 \mathrm{~nm}$ galanin 3-29 produced only a small effect on transmission. After washout of this peptide fragment, application of $100 \mathrm{nM}$ galanin resulted in a significantly larger depression of transmission. For $A-C, a-e$ are the same as in Figure $1 A$. 
Ögren, 1992; Corwin et al., 1993; Crawley et al., 1993; Zini et al., 1993; Sahu et al., 1994). C7, M40, M15, and M32 all proved to have agonist effects in our experiments. Application of C7 (100 $\mathrm{nm})$ caused a reduction $(32.27 \pm 3.52 \%)$ in synaptic transmission in 7 of 15 cases examined, as did M40 (100 nM) $(35.8 \pm 6.15 \% ; 10$ of 15), M15 (100 nM) (33.22 $\pm 4.47 \%$; 9 of 12), and M32 (100-500 nм) $(35.59 \pm 9.34 \% ; n=3)$ (Fig. 2). Thus, in the majority of experiments, application of these "antagonist" peptides resulted in a depression of synaptic transmission, although the magnitude of the depression was less than that observed with galanin. This may indicate partial agonist activity or selective activation of limited subtypes of galanin receptors. In many cases, application of galanin after a response to one of the antagonist peptides resulted in a further depression of synaptic transmission. The application of galanin after C7 produced a $46.07 \pm 9.12 \%$ depression (relative to C7; four of five) (Fig. 4A), and similar effects were seen with M15 (39.88 $\pm 8.06 \%$; four of six) (Fig. $4 B)$, and M40 (37.00 $\pm 17.09 \%$; three of five) (data not shown).

Finally, in a minority of experiments, there was convincing evidence for some antagonist activity associated with the putative galanin antagonists. In three of seven cases, washout of $\mathrm{C} 7$ while in the presence of galanin resulted in a reduction in the evoked current (43.33 $\pm 10.09 \%$ ) (Fig. 4C). M15 and M40 were less active as antagonists, similarly antagonizing the actions of galanin in only one of three and one of five cases, respectively $(36.1 \%$ and $18.5 \%$ ) (data not shown). In some experiments, application of galanin in the presence of one of the antagonist peptides produced no additional effect. It is unclear, however, whether this was caused by occlusion or antagonism of the galanin response.

\section{Mechanisms of action of galanin}

A series of experiments was performed to determine the mechanism by which galanin produced synaptic inhibition in the arcuate nucleus. Activation of $\mathrm{K}^{+}$channels in the presynaptic terminal could serve to shunt the incoming action potential, reducing $\mathrm{Ca}^{2+}$ channel activation and $\mathrm{Ca}^{2+}$ influx, thereby reducing transmitter release (Segev, 1990; Gage, 1992; Graham and Redman, 1994; Miller, 1997). Although no outward currents were observed in any of the cells from which we recorded, it is possible that $\mathrm{K}^{+}$ channel activation in the presynaptic terminal might still occur. However, application of galanin in the presence of $100 \mu \mathrm{M} \mathrm{Ba}^{2+}$, which blocks G-protein-activated $\mathrm{K}^{+}$channels (Ransom and Sontheimer, 1995; Wang and McKinnon, 1996; Rhim et al., 1997), still depressed synaptic transmission to the same extent $(n=4$; data not shown), indicating that $\mathrm{K}^{+}$channel activation was not involved in the actions of galanin in this case. The effects of galanin were also examined using a paired-pulse stimulus protocol (Baskys and Malenka, 1991). Application of galanin (100 nM) was found to depress the initial evoked EPSC, P1, in 6 of 11 cells examined $(57.5 \pm 4.7 \% ; n=6)$ (Fig. $6 A)$. In cases in which a depression of the initial EPSC was observed, the paired-pulse ratio was strongly increased in galanin $\left(\mathrm{P}_{2} / \mathrm{P}_{1}: 1.27 \pm 0.17 ; n=6\right)$ versus control $\left(\mathrm{P}_{2} / \mathrm{P}_{1}: 0.61 \pm 0.05 ; n=6\right)$ (Fig. 5). In contrast, in the cells in which no inhibition of the initial EPSC was observed, the paired-pulse ratio in galanin $(100 \mathrm{nM})\left(\mathrm{P}_{2} / \mathrm{P}_{1}: 1.10 \pm 0.25\right)$ was not significantly different from the control period (1.01 \pm $0.07 ; p=0.740$, unpaired $t$ test; $n=5$; data not shown). Finally, direct postsynaptic modulation of the receptor was examined using a series of short bath applications of AMPA (25 $\mu \mathrm{M}$ for 40 sec). Simultaneous application of galanin had no effect on the whole-cell currents recorded under these conditions (107.7 \pm
$6.5 \%$ of control; $n=6$ ) (data not shown). These effects of galanin support a presynaptic mechanism of action.

Mechanisms underlying modulation of synaptic transmission can also be studied by recording the spontaneous release of vesicles from the presynaptic terminal. Alterations in the frequency or amplitude distribution of miniature events are indicative of a presynaptic or postsynaptic site of action, respectively. mEPSCs were recorded from arcuate nucleus neurons in the presence of 7-chlorokynurenic acid $(40 \mu \mathrm{M})$ or D,L-AP5 $(100 \mu \mathrm{M})$, bicuculline $(10 \mu \mathrm{M})$, TTX $(1 \mu \mathrm{M})$, and $\mathrm{Cd}^{2+}(100 \mu \mathrm{M})$ to isolate $\mathrm{Ca}^{2+}$ entry-independent spontaneous AMPA receptor-mediated events. To confirm that $\mathrm{Cd}^{2+}$ was adequately blocking $\mathrm{Ca}^{2+}$ entry through voltage-gated $\mathrm{Ca}^{2+}$ channels, $100 \mu \mathrm{M} \mathrm{Cd}^{2+}$ was applied to the preparation while evoked EPSCs were recorded. In four of four cases, application of $100 \mu \mathrm{M} \mathrm{Cd}{ }^{2+}$ completely abolished synaptic transmission (data not shown). Under these conditions, spontaneous mEPSCs were observed in approximately one of four cells recorded from at a frequency adequate for analysis $(>0.5 \mathrm{~Hz})$. Application of galanin $(100 \mathrm{~nm})$ resulted in a $54.07 \pm 3.45 \%$ reduction in the frequency of recorded mEPSCs but had no effect on the amplitude distribution $(95.83 \pm 2.06 \%)$ (Fig. $6 A-F)(n=7)$.

$\alpha$-latrotoxin binds to at least two types of presynaptic receptors and enhances transmitter release in both a $\mathrm{Ca}^{2+}$-dependent and -independent manner (Misler and Hurlbut, 1979; Grasso et al., 1980; Nicholls et al., 1982; Meldolesi et al., 1984; Rosenthal et al., 1990; Capogna et al., 1996a; Krasnoperov et al., 1997). When galanin was applied to slices that had been incubated in $2 \mathrm{~nm}$ $\alpha$-latrotoxin, there was a $47.76 \pm 6.33 \%$ reduction in the frequency of mEPSCs (Fig. $7 A-F)(n=7)$. The amplitude distribution remained unchanged $(97.78 \pm 2.70 \%$ of control; $n=7)$ (Fig. $7 A-F$ ). These results suggest that galanin can inhibit transmitter release at a site "downstream" of $\mathrm{Ca}^{2+}$ entry through voltage-dependent $\mathrm{Ca}^{2+}$ channels and may act at a site very close to the final step in the release process.

\section{DISCUSSION}

Galanin acts in the hypothalamus to stimulate feeding behavior (Crawley et al., 1990; Kyrkouli et al., 1990; Leibowitz and Kim, 1992; Corwin et al., 1993) and to regulate hormone secretion (Bauer et al., 1986; Bjorkstrand et al., 1993; Kondo et al., 1993; Landry et al., 1995) and the reproductive cycle (Grafstein-Dunn et al., 1994; Sahu et al., 1994; Rossmanith et al., 1996). In addition, galanin has been shown to exert numerous effects elsewhere in the brain, including effects on learning and memory (Sundström et al., 1988; Ögren and Pramanik, 1991; Crawley et al., 1993).

How does galanin produce its effects? Cloning studies have indicated that the actions of galanin are mediated through at least two subtypes of galanin receptors, GALR1 and GALR2 (HabertOrtoli et al., 1994; Howard et al., 1997). In addition, the existence of other galanin receptors has been inferred from binding and functional studies (Wynick et al., 1993; Gu et al., 1995; Valkna et al., 1995). The effects of galanin we have observed would be expected to involve at least two different receptors. Both GALR1 and GALR2 have been shown to be present within the hypothalamus (Habert-Ortoli et al., 1994; Gustafson et al., 1996; Howard et al., 1997; Wang et al., 1997) and might be responsible for much of the activity observed here using galanin agonists. Furthermore, these receptors also interact with the putative galanin antagonists we have used. The majority of our observations are consistent with the idea that these peptides act as partial agonists, as has 
3494 J. Neurosci., May 15, 1998, 18(10):3489-3500

Kinney et al. • Galanin Inhibition of Presynaptic Release
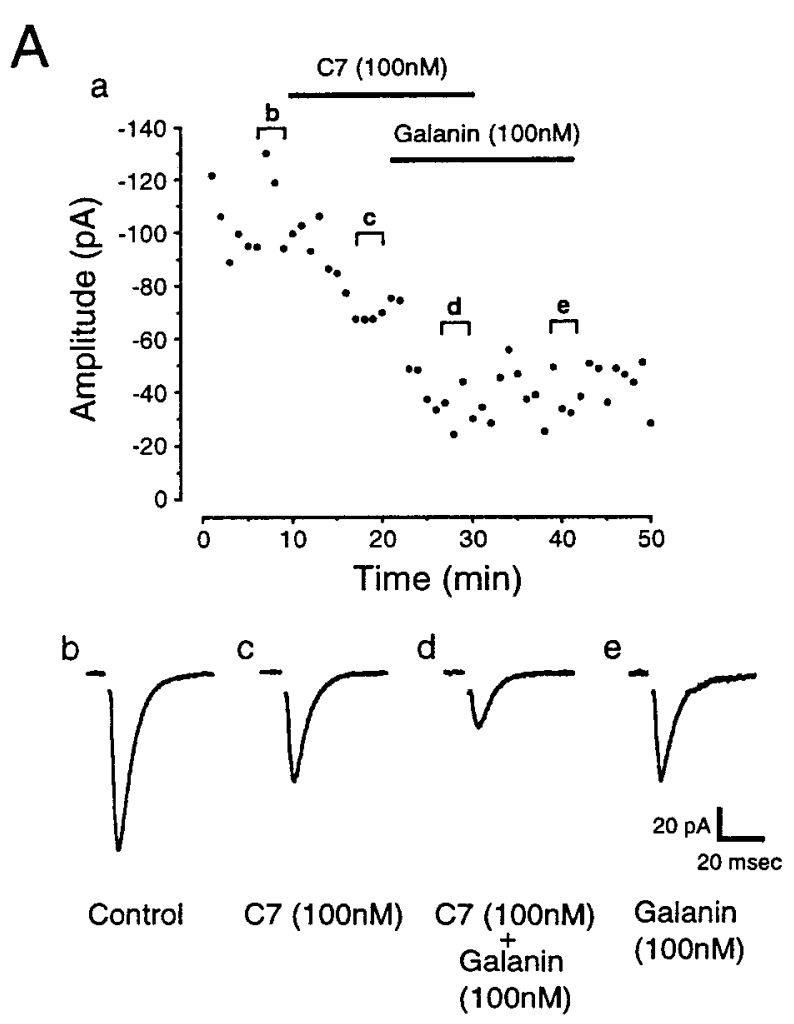
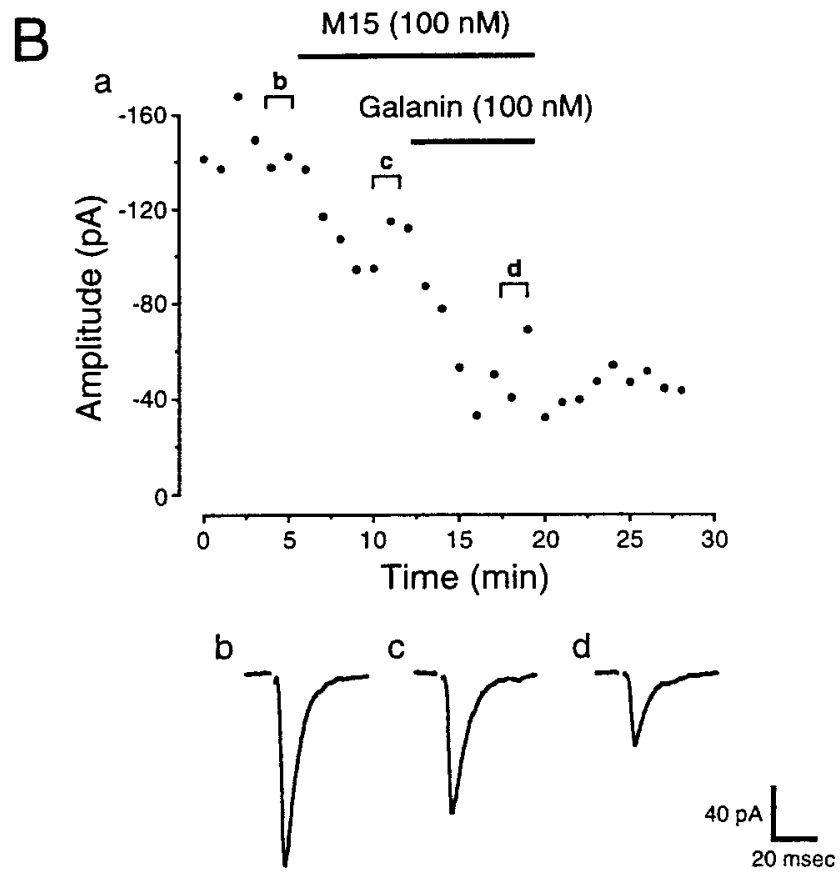

Control M15 (100nM) M15 (100nM) Galanin (100nM)
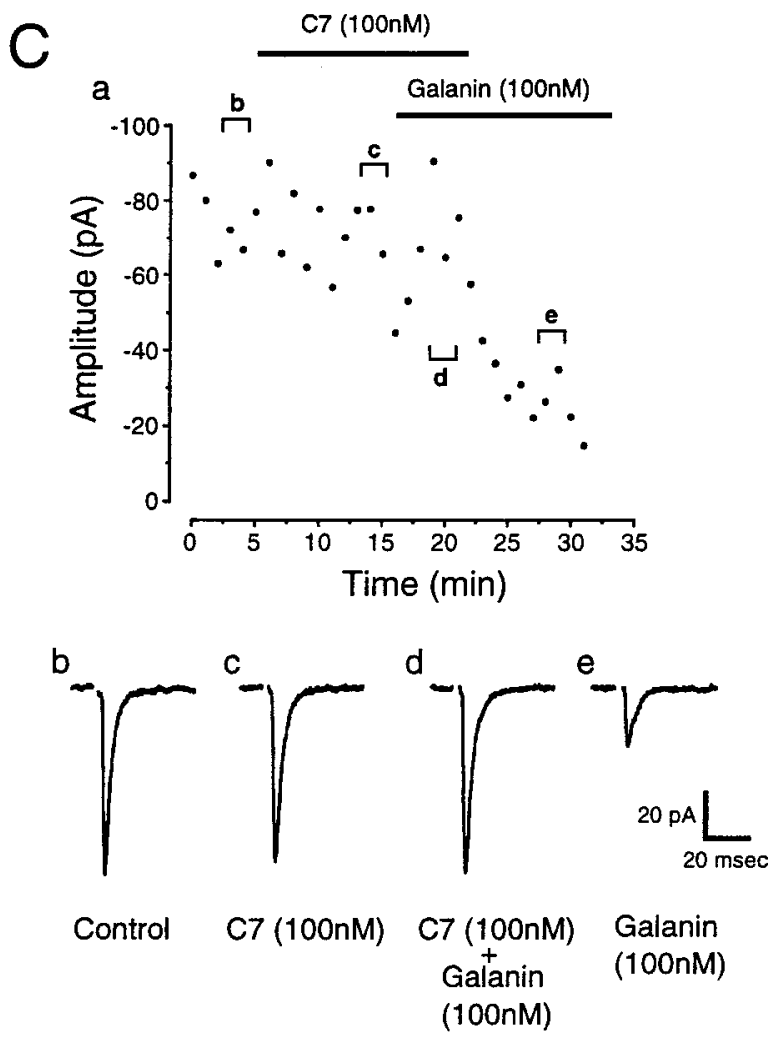

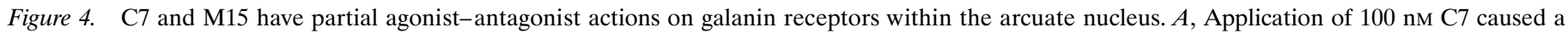

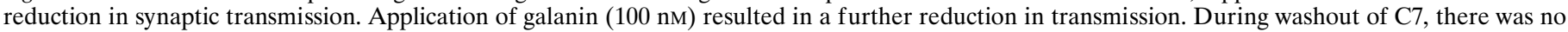

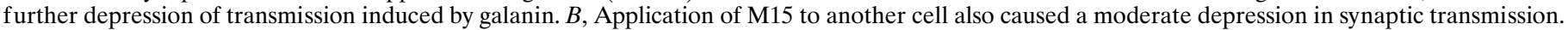

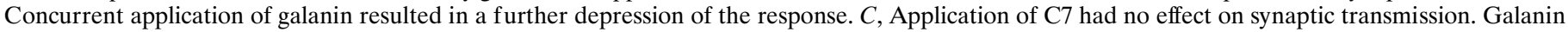

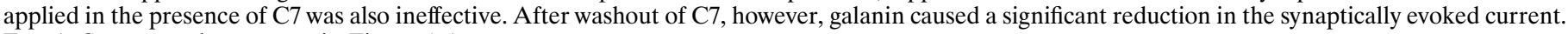
For $A-C, a-e$ are the same as in Figure $1 A$. 

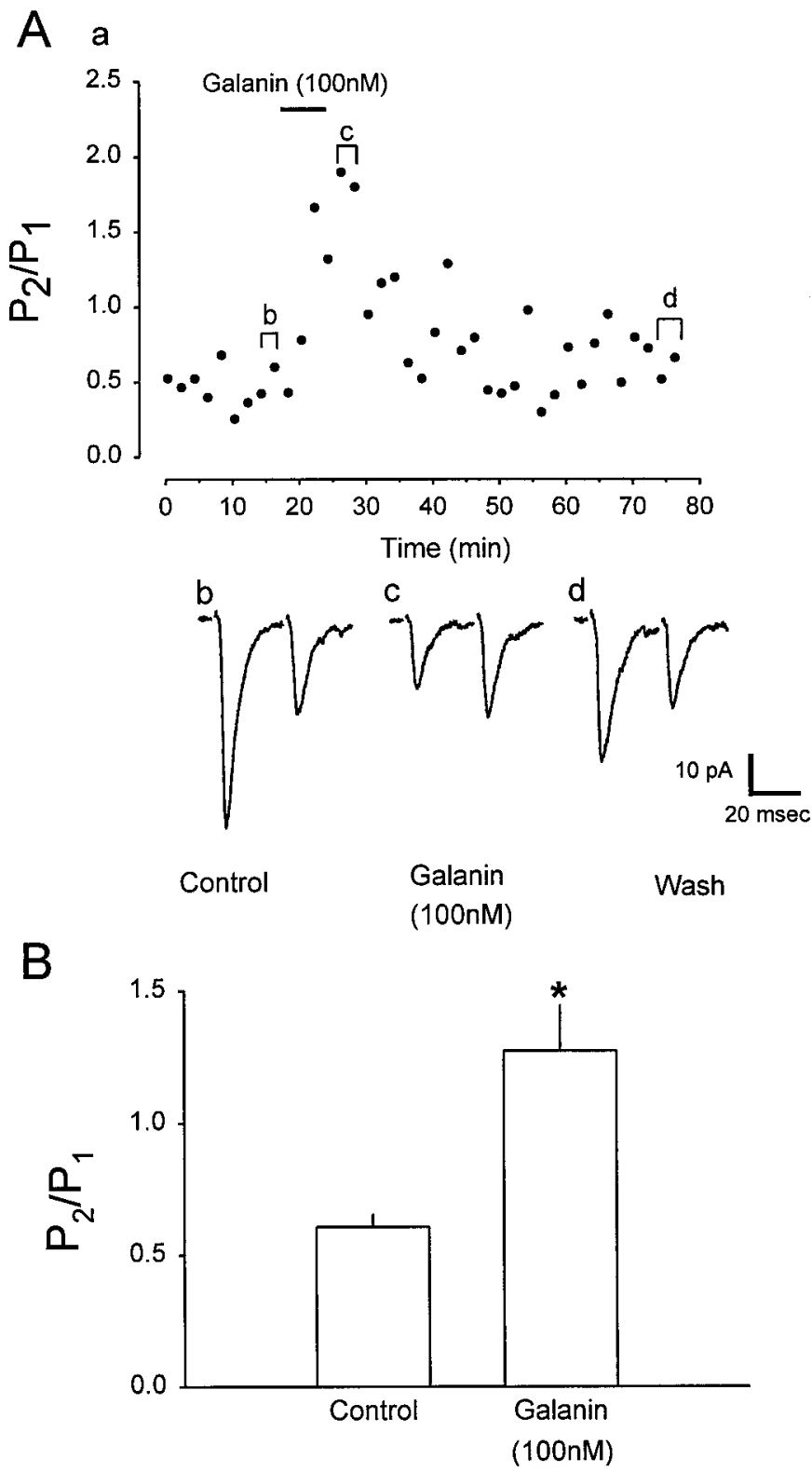

Figure 5. Application of galanin reduced paired-pulse depression in the arcuate nucleus. $A$, Application of $100 \mathrm{~nm}$ galanin produced a reversible decrease in the amplitude of the initial first evoked EPSC, $\mathrm{P}_{1}$, and an increase in the paired-pulse ratio $\mathrm{P}_{2} / \mathrm{P}_{1} . A$, $a$ represents the time course of the effects of galanin on the ratio of the amplitude of the evoked EPSCs, $\mathrm{P}_{2} / \mathrm{P}_{1}$. For $A, b-d$ are the same as in Figure $1 A$. Interpulse interval was 30 msec. $B$, Histogram representing the effect of galanin $(100 \mathrm{nM})$ on the mean paired-pulse depression from six cells. The pooled data show a significant increase in the paired-pulse ratio ( $p=0.01$; unpaired $t$ test).

been found in several other investigations (Fridolf and Ahrén, 1993; Mulvaney et al., 1995; Papas and Bourque, 1997). Additionally, we have made at least two other interesting observations. The first of these concerns the activity of galanin 3-29. This analog does not interact significantly with either GALR1 or GALR2 (Habert-Ortoli et al., 1994; Parker et al., 1995; Howard et al., 1997; Sullivan et al., 1997). However, Wynick et al. (1993) reported that the anterior pituitary and hypothalamus do contain a receptor that is activated by $\mathrm{N}$-terminal truncated analogs such as galanin 3-29. The modest effects we have observed may reflect actions at such a receptor. Second, it is striking that we have observed groups of cells that responded to both galanin 1-16 and $1-15$ or only to the former peptide. It is clear that GALR1 and GALR2 both respond to galanin 1-16 (Habert-Ortoli et al., 1994; Parker et al., 1995; Howard et al., 1997; Sullivan et al., 1997). However, previous studies have generally indicated that the potency of galanin analogs decreases substantially after the removal of the amino acid in the 16th position (Lagny-Pourmir et al., 1989; Land et al., 1991). Thus, the robust activity of galanin 1-15 observed in some cells is somewhat surprising. However, there is a report of a galanin 1-15 selective receptor in the hippocampus (Hedlund et al., 1994), and intracerebroventricular injection of galanin 1-15 but not 1-29 modulates baroreflex sensitivity in the rat (Diaz et al., 1996). Thus, it is conceivable that this receptor also occurs in the hypothalamus.

Further evidence for the presence multiple subtypes of galanin receptors in the arcuate nucleus was obtained in experiments with the chimeric peptides M40, M15, M32, and C7. In the majority of cases, these compounds behaved as agonists. However, the degree of inhibition was notably less than that caused by galanin alone. This may reflect partial agonist actions of these compounds. Alternatively, galanin may act simultaneously at several different subtypes of receptors, whereas the chimeric peptides may be a more selective group of full agonists. Antagonism by the chimeric peptides was observed only in a minority of cases examined. This contrasts with other reports on the actions of these peptides in which they have been shown to block galanin-induced feeding behavior (Leibowitz and Kim, 1992; Corwin et al., 1993; Crawley et al., 1993), stimulation of ACh release (Pramanik and Ögren, 1993), and the actions of galanin in the hippocampus, locus coeruleus, and spinal cord (Bartfai et al., 1991, 1993). However, other reports have suggested partial or full agonist actions of these compounds, including on the mobilization of intracellular $\mathrm{Ca}^{2+}$ stores (Fridolf and Ahrén, 1993), the activation of $\mathrm{K}^{+}$ currents in magnocellular neurosecretory cells (Papas and Bourque, 1997), and in the inhibition of voltage-dependent $\mathrm{Ba}^{2+}$ currents

(Mulvaney et al., 1995). It appears then that the actions of these compounds are not restricted to antagonist effects and that they may even prove to be selective agonists at specific subtypes of galanin receptors. In summary, therefore, our results suggest the existence of multiple types of galanin receptors within the arcuate nucleus. Nevertheless, it is possible that some of the galanin analogs that we are using interact with other receptor populations as well. Additional pharmacological characterization is required before any definitive statements can be made regarding the actions of these compounds.

The actions of galanin on fast glutamatergic transmission observed in this study are analogous to those shown in other reports, such as its effects on slow cholinergic transmission in the hippocampus (Dutar et al., 1989). However, no studies have investigated directly the mechanisms underlying such actions. Galanin inhibited evoked L-glutamate release in the hippocampus, an effect that was blocked by glibenclamide, an ATP-sensitive $\mathrm{K}^{+}$ channel blocker (Zini et al., 1993). In many other systems, galanin activates a $\mathrm{K}^{+}$conductance and hyperpolarizes neurons (Ahrén et al., 1989; Dunne et al., 1989; Konopka et al., 1989; Seutin et al., 1989; Papas and Bourque, 1997), an effect that could produce inhibition of transmitter release (Segev, 1990; Gage, 1992; Graham and Redman, 1994; Miller, 1997). However, in our studies no outward currents were observed with galanin. Furthermore, application of $100 \mu \mathrm{M} \mathrm{Ba}{ }^{2+}$ had no effect on galanin 


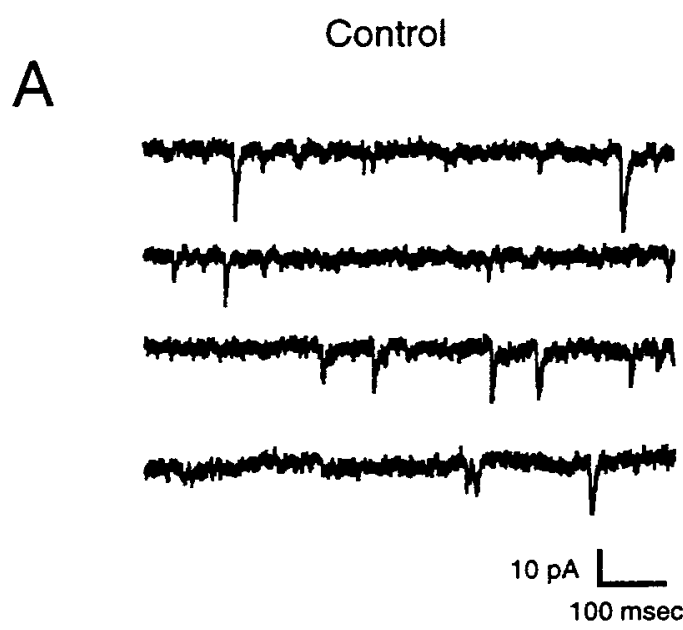

B

Galanin (100 nM)

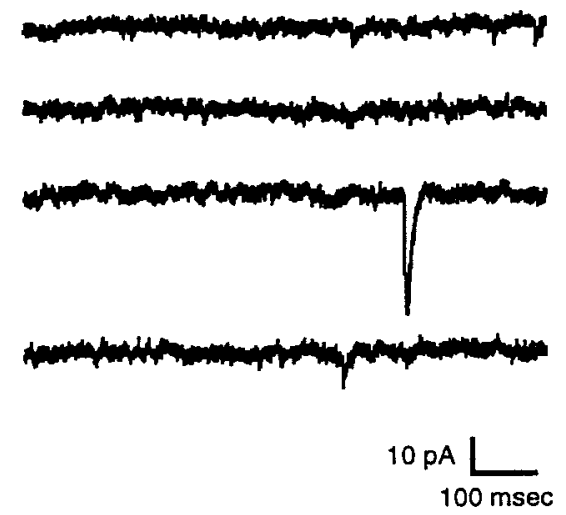

C

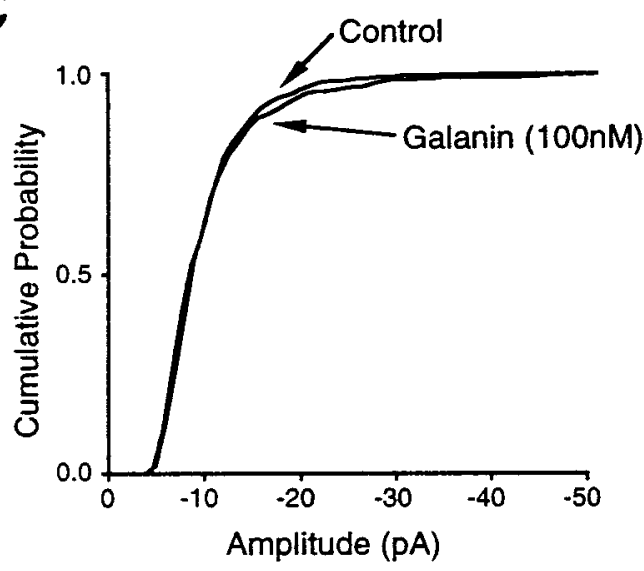

$D$

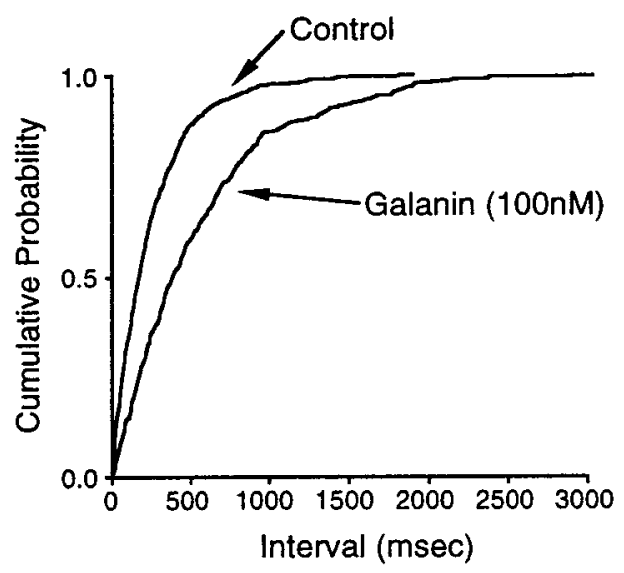

F

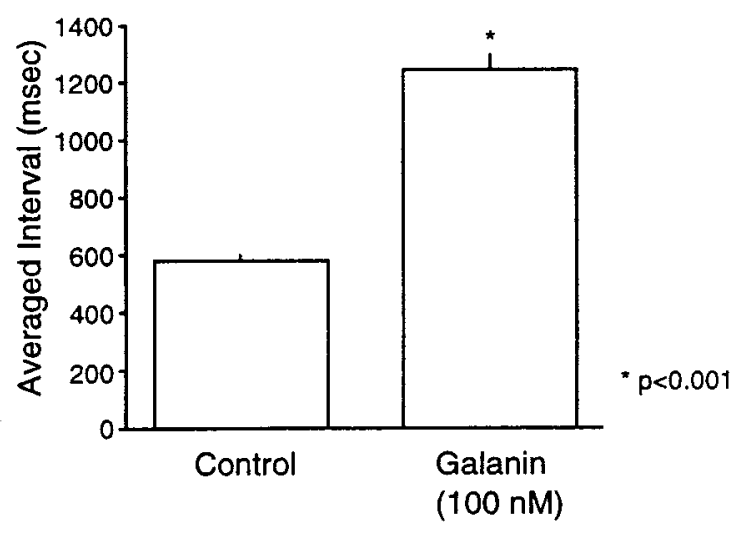

Figure 6. Galanin caused a reduction in the frequency of mEPSCs with no effect on the amplitude distribution. $A$, $B$, Samples of mEPSCs recorded from arcuate nucleus neurons. In both $A$ and $B$, traces represent a continuous recording period of $\sim 3 \sec$ for control $(A)$ and in the presence of 100 nM galanin $(B) . C, D$, Cumulative probability plots of the distribution of mEPSC amplitudes $(C)$ and intervals $(D)$ for a single cell, showing a significant change in the interval distribution ( $p<0.0001$; unpaired $t$ test with Welch's correction). $E, F$, Effect of galanin on the mean amplitude $(E)$ and mean interval $(F)$ for data pooled from six cells. The pooled data showed a significant change in the interval $(p<0.0001$; unpaired $t$ test with Welch's correction), whereas no significant change in the mean amplitude was observed. All data were acquired in the presence of $1 \mu \mathrm{M}$ TTX, $40 \mu \mathrm{M} 7$-chlorokynurenic acid, $10 \mu \mathrm{M}$ bicuculline, and $100 \mu \mathrm{M} \mathrm{Cd^{2+ }}$.

receptor-mediated synaptic depression (Scanziani et al., 1995; Miller, 1997).

There are also reports of galanin inhibiting voltage-gated $\mathrm{Ca}^{2+}$ channels in neurons (Merriam and Parsons, 1995; Mulvaney et al.,
1995), and such an action could contribute to the effects on synaptic transmission that we have observed. We have clearly demonstrated that galanin acts presynaptically to directly decrease transmitter release independent of $\mathrm{Ca}^{2+}$ entry through 


\section{$\alpha$-latrotoxin}

A

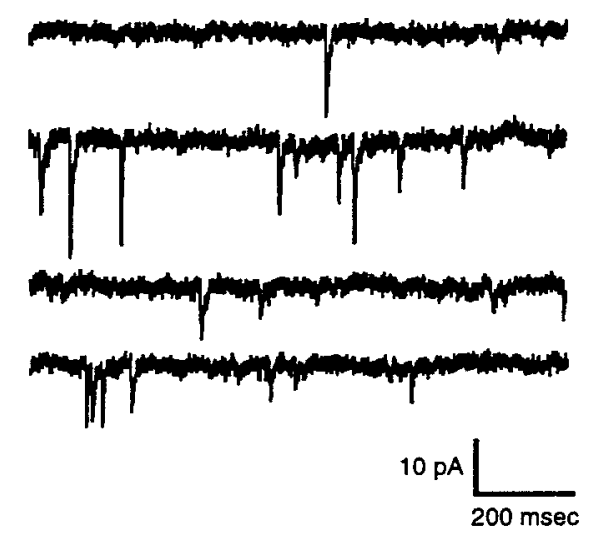

C

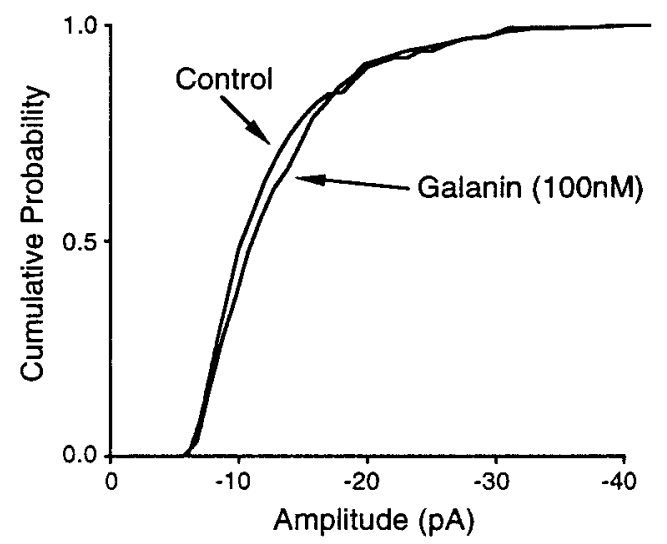

E

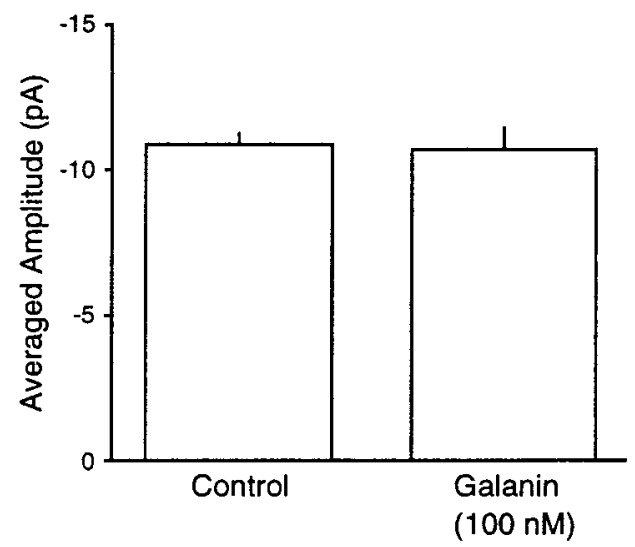

B

Galanin $(100 \mathrm{nM})$
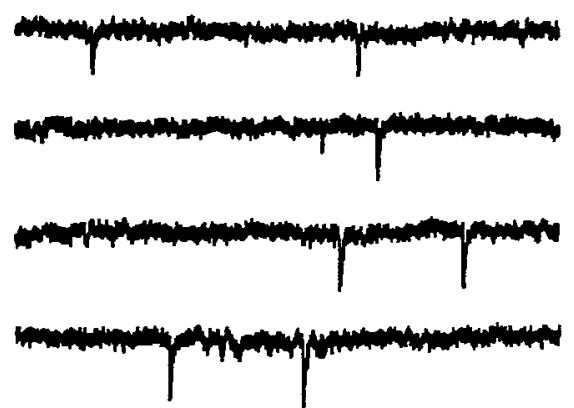

$10 \mathrm{pA}$

$200 \mathrm{msec}$

D

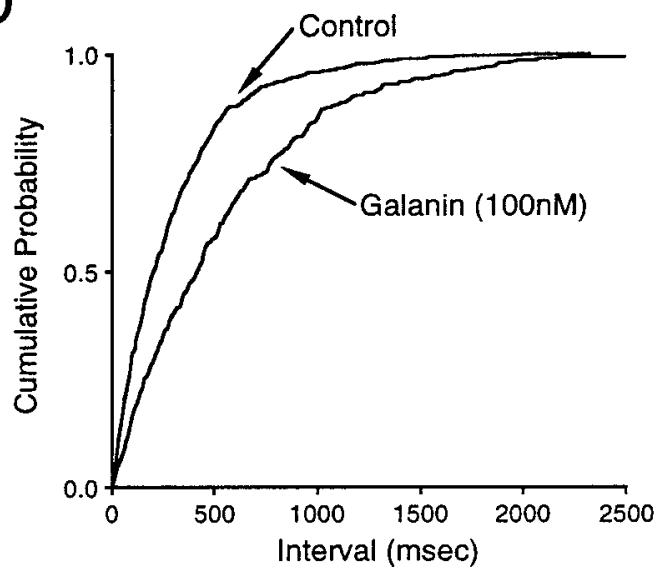

F

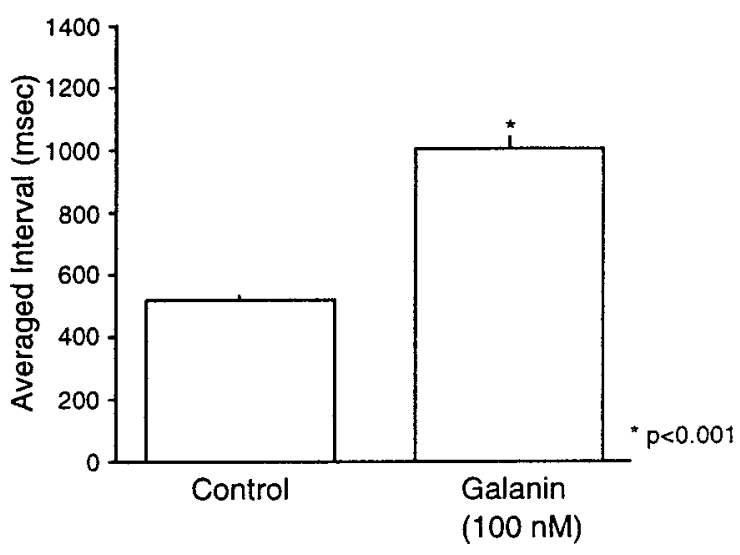

Figure 7. Galanin caused a reduction in the frequency of mEPSCs with no effect on the amplitude distribution in slices exposed to $\alpha$-latrotoxin. $A$, $B$, Samples of mEPSCs recorded from arcuate nucleus neurons in slices exposed to $\alpha$-latrotoxin for $>2 \mathrm{hr}$. In both $A$ and $B$, traces represent a continuous recording period of $\sim 4 \mathrm{sec}$ total for control $(A)$ and in the presence of $100 \mathrm{~nm}$ galanin $(B)$. $C, D$, Cumulative probability plots of the distribution of mEPSC amplitudes $(A)$ and intervals $(B)$ for a single cell, showing a significant change in the interval distribution $(p<0.0001$; unpaired $t$ test with Welch's correction). $C, D$, Effect of galanin on the mean amplitude $(C)$ and mean interval $(D)$ for data pooled from seven cells. The pooled data showed a significant change in the interval ( $p<0.0001$; unpaired $t$ test with Welch's correction), whereas no significant change in the mean amplitude was observed. All data were acquired in the presence of $1 \mu \mathrm{M}$ TTX, $100 \mu \mathrm{M}$ D,L-AP5, $10 \mu \mathrm{M}$ bicuculline, and $100 \mu \mathrm{M}$ Cd ${ }^{2+}$ in slices exposed to 2 nM $\alpha$-latrotoxin for $2 \mathrm{hr}$ before recording. 
voltage-sensitive $\mathrm{Ca}^{2+}$ channels. This mechanism of presynaptic inhibition has now been widely reported in slices and in culture (Scholz and Miller, 1992; Scanziani et al., 1995; Tyler and Lovinger, 1995; Trudeau et al., 1996; Dittman et al., 1996;), although its underlying molecular mechanisms are unclear. It is conceivable, however, that the mechanism of release for mEPSCs versus evoked currents is different, and consequently the mechanism of action of galanin may not be the same for these two processes (but see Capogna et al., 1996a). Interestingly, the magnitude of the effect of galanin on mEPSCs in the presence of $\mathrm{Cd}^{2+}(54.07 \pm 3.45 \%$ reduction in frequency) was similar to the effect of galanin on synaptic transmission $(55.54 \pm 4.03 \%$ reduction in amplitude), indicative of a common mechanism. Significant, however, was the observation that galanin decreased the magnitude of paired-pulse depression, often reversing it to paired-pulse facilitation, indicative of a presynaptic action on evoked release (Baskys and Malenka, 1991). It is still possible, however, that galanin is acting on a $\mathrm{Ca}^{2+}$-dependent mechanism. Residual $\mathrm{Ca}^{2+}$ inside the cell, or $\mathrm{Ca}^{2+}$ leak into the cell, might contribute to mEPSC frequency even in the presence of $\mathrm{Cd}^{2+}$. However, $\alpha$-latrotoxin acts at the presynaptic terminal to induce a partially $\mathrm{Ca}^{2+}$-independent release of transmitter (Misler and Hurlbut, 1979; Meldolesi et al., 1984; Rosenthal et al., 1990; Capogna et al., 1996a; Krasnoperov et al., 1997). Exposure of the slices to $\alpha$-latrotoxin would activate this mechanism, and thus a significant portion of the resultant mEPSCs would be $\mathrm{Ca}^{2+}$ independent. Under these conditions, application of galanin resulted in inhibition of mEPSCs of a magnitude comparable to that observed in the absence of $\alpha$-latrotoxin $(47.76 \pm 6.33 \%$ reduction in frequency). These results are similar to those reported for the actions of GABA in the hippocampus in the presence of $\alpha$-latrotoxin (Capogna et al., 1996a) and suggest that galanin has a powerful depressant effect on the release process at a site close to the final vesicle-release step. There are numerous potential sites within the presynaptic machinery at which it could act. Krasnoperov et al. (1997) reported recently that $\alpha$-latrotoxin stimulates $\mathrm{Ca}^{2+}$-independent exocytosis through its interaction with a G-protein-coupled receptor (the CIRL-receptor), and that this receptor copurifies with syntaxin. Furthermore, Linial et al. (1997) reported that presynaptic muscarinic receptors could also directly interact with syntaxin. Thus, the galanin receptor might interact with, or signal to, a site within the release machinery and so directly reduce exocytosis.

\section{REFERENCES}

Ahrén B, Berggren PO, Bokvist K, Rorsman P (1989) Does galanin inhibit insulin secretion by opening of the ATP-regulated $\mathrm{K}^{+}$channel in the beta-cell? Peptides 10:453-457.

Bartfai T, Bedecs K, Land T, Langel U, Bertorelli R, Girotti P, Consolo S, Xu XJ, Wiesenfeld-Hallin Z, Nilsson S, Pieribone VA, Hökfelt T (1991) M-15: high-affinity chimeric peptide that blocks the neuronal actions of galanin in the hippocampus, locus coeruleus, and spinal cord. Proc Natl Acad Sci USA 88:10961-10965.

Bartfai T, Langel U, Bedecs K, Andell S, Land T, Gregersen S, Ahrén B, Girotti P, Consolo S, Corwin R, Crawley J, Xu X, Wiesenfeld-Hallin Z, Hökfelt T (1993) Galanin-receptor ligand M40 peptide distinguishes between putative galanin-receptor subtypes. Proc Natl Acad Sci USA 90:11287-11291.

Baskys A, Malenka RC (1991) Agonists at metabotropic glutamate receptors presynaptically inhibit EPSCs in neonatal rat hippocampus. J Physiol (Lond) 444:687-701.

Bauer FE, Ginsberg L, Venetikou M, MacKay DJ, Burrin JM, Bloom SR (1986) Growth hormone release in man induced by galanin, a new hypothalamic peptide. Lancet 26:192-195.

Bjorkstrand E, Hulting AL, Meister B, Uvnas-Moberg K (1993) Effect of galanin on plasma levels of oxytocin and cholecystokinin. NeuroReport $4: 10-12$.

Capogna M, Gahwiler BH, Thompson SM (1996a) Presynaptic inhibition of calcium-dependent and -independent release elicited with ionomycin, gadolinium, and alpha-latrotoxin in the hippocampus. J Neurophysiol 75:2017-2028.

Capogna M, Gahwiler BH, Thompson SM (1996b) Calciumindependent actions of alpha-latrotoxin on spontaneous and evoked synaptic transmission in the hippocampus. J Neurophysiol 76: 3149-3158.

Chen Y, Laburthe M, Amiranoff B (1992) Galanin inhibits adenylate cyclase of rat brain membranes. Peptides 13:339-341.

Corwin RL, Robinson JK, Crawley JN (1993) Galanin antagonists block galanin-induced feeding in the hypothalamus and amygdala of the rat. Eur J Neurosci 5:1528-1533.

Crawley JN, Austin MC, Fiske SM, Martin B, Consolo S, Berthold M, Langel U, Fisone G, Bartfai T (1990) Activity of centrally administered galanin fragments on stimulation of feeding behavior and on galanin receptor binding in the rat hypothalamus. J Neurosci 1990 10:3695-3700.

Crawley JN, Robinson JK, Langel U, Bartfai T (1993) Galanin receptor antagonists M40 and C7 block galanin-induced feeding. Brain Res 600:268-272.

Diaz Z, Narvaez JA, Hedlund PB, Aguirre JA, Gonzalez-Baron S, Fuxe K (1996) Centrally infused galanin-(1-15) but not galanin-(1-29) reduces the baroreceptor reflex sensitivity in the rat. Brain Res 741:32-37.

Dittman JS, Regehr WG (1996) Contributions of calcium-dependent and calcium-independent mechanisms to presynaptic inhibition at a cerebellar synapse. J Neurosci 16:1623-1633.

Dobrunz LE, Stevens CF (1997) Heterogeneity of release probability, facilitation, and depletion at central synapses. Neuron 18:995-1008.

Dunne MJ, Bullett MJ, Li GD, Wollheim CB, Petersen OH (1989) Galanin activates nucleotide-dependent $\mathrm{K}^{+}$channels in insulinsecreting cells via a pertussis toxin-sensitive G-protein. EMBO J 8:413-420.

Dutar P, Lamour Y, Nicoll RA (1989) Galanin blocks the slow cholinergic EPSP in CA1 pyramidal neurons from ventral hippocampus. Eur J Pharmacol 164:355-360.

Edwards FA, Konnerth A, Sakmann B, Takahashi T (1989) A thin slice preparation for patch clamp recording from neurones of the mammalian central nervous system. Pflügers Arch 414:600-612.

Fisone $\mathrm{G}, \mathrm{Wu} \mathrm{CF}$, Consolo S, Nordstrom O, Brynne N, Bartfai T, Melander T, Hokfelt T (1987) Galanin inhibits acetylcholine release in the ventral hippocampus of the rat: histochemical, autoradiographic, in vivo, and in vitro studies. Proc Natl Acad Sci USA 84:7339-7343.

Fridolf T, Ahrén B (1993) Dual action of the neuropeptide galanin on the cytoplasmic free calcium concentration in RIN m5F cells. Biochem Biophys Res Commun 191:1224-1229.

Gage PW (1992) Activation and modulation of neuronal $\mathrm{K}^{+}$channels by GABA. Trends Neurosci 15:46-51.

Glaum SR, Alford S, Rossi DJ, Collingridge GL, Slater NT (1994) Whole cell patch recording with simultaneous measurement of intracellular calcium concentration in mammalian brain slices in vitro. Methods Neurosci 19:340-358.

Glaum SR, Hara M, Bindokas VP, Lee CC, Polonsky KS, Bell GI, Miller RJ (1996) Leptin, the obese gene product, rapidly modulates synaptic transmission in the hypothalamus. Mol Pharmacol 50:230-235.

Grafstein-Dunn E, Clifton DK, Steiner RA (1994) Regulation of galanin and gonadotropin-releasing hormone gene expression in the hypothalamus and basal forebrain of the rat. Horm Behav 28:417-423.

Graham B, Redman S (1994) A simulation of action potentials in synaptic boutons during presynaptic inhibition. J Neurophysiol 71: $538-549$.

Grasso A, Alema S, Rufini S, Senni MI (1980) Black widow spider toxin-induced calcium fluxes and transmitter release in a neurosecretory cell line. Nature 283:774-776.

Gu ZF, Pradhan TK, Coy DH, Jensen RT (1995) Interaction of galanin fragments with galanin receptors on isolated smooth muscle cells from guinea pig stomach: identification of a novel galanin receptor subtype. J Pharmacol Exp Ther 272:371-378.

Gustafson EL, Smith KE, Durkin MM, Gerald C, Branchek TA (1996) Distribution of a rat galanin receptor mRNA in rat brain. NeuroReport 7:953-957.

Habert-Ortoli E, Amiranoff B, Loquet I, Laburthe M, Mayaux JF (1994) 
Molecular cloning of a functional human galanin receptor. Proc Natl Acad Sci USA 91:9780-9783.

Hamill OP, Marty A, Neher E, Sakmann B, Sigworth FJ (1981) Improved patch-clamp techniques for high resolution current recording from cells and cell-free membrane patches. Pflügers Arch 391:85-100.

Hedlund PB, Finnman UB, Yanaihara N, Fuxe K (1994) Galanin-(1-15), but not galanin-(1-29), modulates 5-HT1A receptors in the dorsal hippocampus of the rat brain: possible existence of galanin receptor subtypes. Brain Res 634:163-167.

Howard AD, Tan C, Shiao LL, Palyha OC, McKee KK, Weinberg DH, Feighner SD, Cascieri MA, Smith RG, Van Der Ploeg LH, Sullivan KA (1997) Molecular cloning and characterization of a new receptor for galanin. FEBS Lett 405:285-290.

Hurlbut WP, Iezzi N, Fesce R, Ceccarelli B (1990) Correlation between quantal secretion and vesicle loss at the frog neuromuscular junction. J Physiol (Lond) 425:501-526.

Khazipov R, Congar P, Ben-Ari Y (1995) Hippocampal CA1 lacunosum-moleculare interneurons: modulation of monosynaptic GABAergic IPSCs by presynaptic GABA(B) receptors. J Neurophysiol 74:2126-2137.

Kondo K, Murase T, Otake K, Ito M, Kurimoto F, Oiso Y (1993) Galanin as a physiological neurotransmitter in hemodynamic control of arginine vasopressin release in rats. Neuroendocrinology 57:224-229.

Konopka LM, McKeon TW, Parsons RL (1989) Galanin-induced hyperpolarization and decreased membrane excitability of neurones in mudpuppy cardiac ganglia. J Physiol (Lond) 410:107-122.

Krasnoperov VG, Bittner MA, Beavis R, Kuang Y, Salnikow KV, Chepurny OG, Little AR, Plotnikov AN, Wu D, Holz RW, Petrenko AG (1997) alpha-Latrotoxin stimulates exocytosis by the interaction with a neuronal G-protein-coupled receptor. Neuron 18:925-937.

Kyrkouli SE, Stanley BG, Seirafi RD, Leibowitz SF (1990) Stimulation of feeding by galanin: anatomical localization and behavioral specificity of this peptide's effects in the brain. Peptides 11:995-1001.

Lagny-Pourmir I, Lorinet AM, Yanaihara N, Laburthe M (1989) Structural requirements for galanin interaction with receptors from pancreatic beta cells and from brain tissue of the rat. Peptides 10:757-761.

Land T, Langel U, Low M, Berthold M, Unden A, Bartfai T (1991) Linear and cyclic $\mathrm{N}$-terminal galanin fragments and analogs as ligands at the hypothalamic galanin receptor. Int J Pept Protein Res 38: 267-272.

Landry M, Roche D, Calas A (1995) Short-term effects of centrally administered galanin on the hyperosmotically stimulated expression of vasopressin in the rat hypothalamus. An in situ hybridization and immunohistochemistry study. Neuroendocrinology 61:393-404.

Leibowitz SF, Kim T (1992) Impact of a galanin antagonist on exogenous galanin and natural patterns of fat ingestion. Brain Res 599: $148-152$.

Lindskog S, Ahrén B, Land T, Langel U, Bartfai T (1992) The novel high-affinity antagonist, galantide, blocks the galanin-mediated inhibition of glucose-induced insulin secretion. Eur J Pharmacol 210:183-188.

Linial M, Ilouz N, Parnas H (1997) Voltage-dependent interaction between the muscarinic ACh receptor and proteins of the exocytic machinery. J Physiol (Lond) 504:251-258.

Lorinet AM, Javoy-Agid F, Laburthe M, Amiranoff B (1994) Galanin receptors in human hypothalamus: biochemical and structural analysis. Eur J Pharmacol 269:59-64.

McMahon HT, Rosenthal L, Meldolesi J, Nicholls DG (1990) Alphalatrotoxin releases both vesicular and cytoplasmic glutamate from isolated nerve terminals. J Neurochem 55:2039-2047.

Melander T, Hokfelt T, Rokaeus A (1986) Distribution of galaninlike immunoreactivity in the rat central nervous system. J Comp Neurol 248:475-517.

Meldolesi J, Huttner WB, Tsien RY, Pozzan T (1984) Free cytoplasmic $\mathrm{Ca}^{2+}$ and neurotransmitter release: studies on PC12 cells and synaptosomes exposed to alpha-latrotoxin. Proc Natl Acad Sci USA 81:620-624.

Merchenthaler I, Lopez FJ, Negro-Vilar A (1993) Anatomy and physiology of central galanin-containing pathways. Prog Neurobiol 40:711-769.

Merriam LA, Parsons RL (1995) Neuropeptide galanin inhibits omegaconotoxin GVIA-sensitive calcium channels in parasympathetic neurons. J Neurophysiol 73:1374-1382.

Miller RJ (1997) Presynaptic receptors. Annu Rev Neurosci, in press.

Misler S, Hurlbut WP (1979) Action of black widow spider venom on quantized release of acetylcholine at the frog neuromuscular junction: dependence upon external $\mathrm{Mg}^{2+}$. Proc Natl Acad Sci USA 76:991-995.

Mulvaney JM, Merriam LA, Parsons RL (1995) Galantide distinguishes putative subtypes of galanin receptors in mudpuppy parasympathetic neurons. Eur J Pharmacol 287:97-100.

Nicholls DG, Rugolo M, Scott IG, Meldolesi J (1982) alpha-latrotoxin of black widow spider venom depolarizes the plasma membrane, induces massive calcium influx, and stimulates transmitter release in guinea pig brain synaptosomes. Proc Natl Acad Sci USA 79:7924-7928.

Nishibori M, Oishi R, Itoh Y, Saeki K (1988) Galanin inhibits noradrenaline-induced accumulation of cyclic AMP in the rat cerebral cortex. J Neurochem 51:1953-1955.

Nordström O, Melander T, Hokfelt T, Bartfai T, Goldstein M (1987) Evidence for an inhibitory effect of the peptide galanin on dopamine release from the rat median eminence. Neurosci Lett 73:21-26.

Ögren SO, Pramanik A (1991) Galanin stimulates acetylcholine release in the rat striatum. Neurosci Lett 128:253-256.

Ögren SO, Pramanik A, Land T, Langel U (1993) Differential effects of the putative galanin receptor antagonists M15 and M35 on striatal acetylcholine release. Eur J Pharmacol 42:59-64.

Palazzi E, Fisone G, Hokfelt T, Bartfai T, Consolo S (1988) Galanin inhibits the muscarinic stimulation of phosphoinositide turnover in rat ventral hippocampus. Eur J Pharmacol 148:479-480.

Papas S, Bourque CW (1997) Galanin inhibits continuous and phasic firing in rat hypothalamic magnocellular neurosecretory cells. J Neurosci 17:6048-6056.

Parker EM, Izzarelli DG, Nowak HP, Mahle CD, Iben LG, Wang J, Goldstein ME (1995) Cloning and characterization of the rat GALR1 galanin receptor from Rin14B insulinoma cells. Brain Res Mol Brain Res 34:179-189.

Parsons RL, Merriam LA (1992) Galanin and bethanechol appear to activate the same inwardly rectifying potassium current in mudpuppy parasympathetic neurons. Neurosci Lett 140:33-36.

Pramanik A, Ögren SO (1992) Galanin-evoked acetylcholine release in the rat striatum is blocked by the putative galanin antagonist M15. Brain Res 574:317-319.

Pramanik A, Ögren SO (1993) Galanin stimulates striatal acetylcholine release via a mechanism unrelated to cholinergic receptor stimulation. Regul Pept 45:353-362.

Ransom CB, Sontheimer H (1995) Biophysical and pharmacological characterization of inwardly rectifying $\mathrm{K}^{+}$currents in rat spinal cord astrocytes. J Neurophysiol 73:333-346.

Rhim H, Kinney GA, Emmerson PJ, Miller RJ (1997) Regulation of neurotransmission in the arcuate nucleus of the rat by different neuropeptide Y receptors. J Neurosci 17:2980-2989.

Rosenthal L, Zacchetti D, Madeddu L, Meldolesi J (1990) Mode of action of alpha-latrotoxin: role of divalent cations in $\mathrm{Ca} 2(+)$ dependent and $\mathrm{Ca} 2(+)$-independent effects mediated by the toxin. Mol Pharmacol 38:917-923.

Rossmanith WG, Clifton DK, Steiner RA (1996) Galanin gene expression in hypothalamic GnRH-containing neurons of the rat: a model for autocrine regulation. Horm Metab Res 28:257-266.

Sahu A, Xu B, Kalra SP (1994) Role of galanin in stimulation of pituitary luteinizing hormone secretion as revealed by a specific receptor antagonist, galantide. Endocrinology 134:529-536.

Scanziani M, Gahwiler BH, Thompson SM (1995) Presynaptic inhibition of excitatory synaptic transmission by muscarinic and metabotropic glutamate receptor activation in the hippocampus: are $\mathrm{Ca}^{2+}$ channels involved? Neuropharmacology 34: 1549-1557.

Scholz KP, Miller RJ (1992) Inhibition of quantal transmitter release in the absence of calcium influx by a $\mathrm{G}$ protein-linked adenosine receptor at hippocampal synapses. Neuron 8:1139-1150.

Segev I (1990) Computer study of presynaptic inhibition controlling the spread of action potentials into axonal terminals. J Neurophysiol 63:987-998

Seutin V, Verbanck P, Massotte L, Dresse A (1989) Galanin decreases the activity of locus coeruleus neurons in vitro. Eur J Pharmacol 164:373-376.

Skofitsch G, Jacobowitz DM (1985) Immunohistochemical mapping of galanin-like neurons in the rat central nervous system. Peptides 6:509-546.

Storchak LG, Pashkov VN, Pozdnyakova NG, Himmelreich NH, Grishin EV (1994) alpha-Latrotoxin-stimulated GABA release can occur in $\mathrm{Ca}(2+)$-free, $\mathrm{Na}(+)$-free medium. FEBS Lett 351:267-270.

Sullivan KA, Shiao LL, Cascieri MA (1997) Pharmacological character- 
ization and tissue distribution of the human and rat GALR1 receptors. Biochem Biophys Res Commun 233:823-828.

Sundström E, Archer T, Melander T, Hokfelt T (1988) Galanin impairs acquisition but not retrieval of spatial memory in rats studied in the Morris swim maze. Neurosci Lett 88:331-335.

Trudeau LE, Doyle RT, Emery DG, Haydon PG (1996) Calciumindependent activation of the secretory apparatus by ruthenium red in hippocampal neurons: a new tool to assess modulation of presynaptic function. J Neurosci 16:46-54.

Tsuda K, Yokoo H, Goldstein M (1989) Neuropeptide Y and galanin in norepinephrine release in hypothalamic slices. Hypertension 14:81-86.

Tyler EC, Lovinger DM (1995) Metabotropic glutamate receptor modulation of synaptic transmission in corticostriatal co-cultures: role of calcium influx. Neuropharmacology 34:939-952.

Tzeng MC, Cohen RS, Siekevitz P (1978) Release of neurotransmitters and depletion of synaptic vesicles in cerebral cortex slices by alphalatrotoxin from black widow spider venom. Proc Natl Acad Sci USA 75:4016-4020.

Valkna A, Jureus A, Karelson E, Zilmer M, Bartfai T, Langel U (1995) Differential regulation of adenylate cyclase activity in rat ventral and dorsal hippocampus by rat galanin. Neurosci Lett 187:75-78.

Van den Pol AN, Obietan K, Chen G, Belousov AB (1996) Neuropep- tide Y-mediated long-term depression of excitatory activity in suprachiasmatic nucleus neurons. J Neurosci 16:5883-5895.

Vrontakis ME, Torsello A, Friesen HG (1991) Galanin. J Endocrinol Invest 14:785-794.

Wang HS, McKinnon D (1996) Modulation of inwardly rectifying currents in rat sympathetic neurons by muscarinic receptors. J Physiol (Lond) 492:467-478.

Wang S, Hashemi T, He C, Strader C, Bayne M (1997) Molecular cloning and pharmacological characterization of a new galanin receptor subtype. Mol Pharmacol 52:337-343.

Wanke E, Ferroni A, Gattanini P, Meldolesi J (1986) alpha-Latrotoxin of the black widow spider venom opens a small, non-closing cation channel. Biochem Biophys Res Commun 134:320-325.

Wynick D, Smith DM, Ghatei M, Akinsanya K, Bhogal R, Purkiss P, Byfield P, Yanaihara N, Bloom SR (1993) Characterization of a highaffinity galanin receptor in the rat anterior pituitary: absence of biological effect and reduced membrane binding of the antagonist M15 differentiate it from the brain/gut receptor. Proc Natl Acad Sci USA 90:4231-4235.

Zini S, Roisin MP, Langel U, Bartfai T, Ben-Ari Y (1993) Galanin reduces release of endogenous excitatory amino acids in the rat hippocampus. Eur J Pharmacol 245:1-7. 